\title{
Physico-chemical evaluation of fruits from the fourth filial generation of some breeding lines of tomatoes
}

\author{
Wisdom Selorm Kofi Agbemavor ${ }^{1}$, Wellington Torgby-Tetteh ${ }^{1}$, Emmanuel Kwatei Quartey ${ }^{2}$, \\ Joseph Nunoo ${ }^{2}$, Wonder Nunekpeku ${ }^{2}$, Mavis Owureku-Asare', Joyce Agyei-Amponsah ${ }^{1}$, \\ John Apatey ${ }^{1}$ \\ ${ }^{1}$ Radiation Technology Centre of Biotechnology and Nuclear Agriculture Research Institute, Ghana Atomic Energy Commission, \\ Legon-Accra, Ghana \\ ${ }^{2}$ Nuclear Agriculture Research Centre of Biotechnology and Nuclear Agriculture Research Institute, Ghana Atomic Energy Commission, \\ Legon-Accra, Ghana
}

\section{Email address:}

wakselorm@gmail.com (W. S. K. Agbemavor), wtorgbytetteh@yahoo.com (W. Torgby-Tetteh), emmaquart@yahoo.com (E. K. Quartey), joenunoo85@gmail.com (J. Nunoo),nuswonder@gmail.com (W. Nunekpeku), mowureku.asare@gmail.com (M. Owureku-Asare), ampjoyce@gmail.com (J. Agyei-Amponsah),kudjoeapatey2000@yahoo.co.uk (J. Apatey)

\section{To cite this article:}

Wisdom Selorm Kofi Agbemavor, Wellington Torgby-Tetteh, Emmanuel Kwatei Quartey, Joseph Nunoo, Wonder Nunekpeku, Mavis Owureku-Asare, Joyce Agyei-Amponsah, John Apatey. Physico-Chemical Evaluation of Fruits from the Fourth Filial Generation of Some Breeding Lines of Tomatoes. International Journal of Nutrition and Food Sciences. Vol. 3, No. 4, 2014, pp. 318-325.

doi: $10.11648 /$ j.ijnfs.20140304.23

\begin{abstract}
In an effort to improve upon tomato varieties on the Ghanaian market, this study was carried out to identify genotypes with desirable qualities for further breeding work. The study was executed by crossing some varieties of Solanum lycopersicon; cherry red, cherry yellow, roma and wosowoso with a wild tomato, Solanum pimpinellifolium. The progenies were cultivated for four generations to obtain these lines. Fruits harvested from these lines of $\mathrm{F}_{4}$ were analysed for the following physico-chemical properties; dry matter, $\mathrm{pH}$, total titratable acidity, total soluble solids and vitamin $\mathrm{C}$. The total soluble solids and total titratable acidity were used to deduce flavour and sweetness indices for the fruits. Significant $(\mathrm{p}<0.05)$ differences were observed among and within the various breeding lines. The dry matter, $\mathrm{pH}$ and total soluble solids of the fruits ranged from 5.21-8.43\%, 4.08-4.59 and 4.00-7.80\% respectively. Total titratable acidity, ascorbic acid, flavour and sweetness indices also ranged from 0.35-0.88\%, 16.84-46.09 mg/100g, 0.07-0.16 and 5.33-13.64 respectively. In all wosowoso breeding lines were the most promising of all the breeding lines. Most of the progenies obtained had characteristics significantly $(\mathrm{p}<0.05)$ different from each other and then from those of their respective parents (controls). This shows that the various lines were still in the process of segregating and had not yet attained the status of pure lines.
\end{abstract}

Keywords: Tomatoes, Breeding Lines, Physico-Chemical, Progenies

\section{Introduction}

Tomato (Solanum lycopersicon L.) is a herbaceous annual crop. It is one of the most widely consumed vegetable and used in most local dishes in Ghana [1]. It is the second most important vegetable in dollar value and the greatest source of vitamins and minerals in the United States [2]. Just as other fresh fruits and vegetables, tomato fruit is a very important source of vitamins $\mathrm{A}$ and $\mathrm{C}$ and minerals such as potassium, calcium, magnesium and phosphorus that are essential for healthy human diets [3].

Several characteristics such as dry matter, soluble solids, sugar, acidity and $\mathrm{pH}$ are essential fruit quality parameters for both fresh and processed tomatoes. The flavour of tomatoes is dependent on the amount of sugar and acids present. The relative amounts of constituent sugars and acids as well as their interactions play very significant roles in the sweetness, sourness and overall flavour intensity in tomatoes [4]. High sugars and relatively high acids are required for best flavour. High acids and low sugars will produce a sour tomato while high sugars and low acids will result in a tasteless tomato [5-6]. Soluble solids and titratable acidities are the main components responsible for tomato flavour [6] and properties most likely to match the consumer 
perception of the internal quality [7-8].

High dry matter and soluble solids are desirable characteristics for tomato canning industry. These properties improve the quality of the processed product [9]. Higher solid content in fruits reduces processing cost. The mineral component generally contributes about $8 \%$ of the total dry matter of the fruit [10]. The vitamins component accounts for a very small portion of the total dry matter.

Generally tomato fruit consists of $94-95 \%$ water and $5-6 \%$ organic compounds (solids) of which about 1\% is skin and seeds. The percentage of solids in tomato varies for a number of reasons, such as variety, character of oil and especially the amount of irrigation and rainfall during the growing and harvesting season [11]. According to [12], total soluble solids (TSS) content is the most important quality criterion for tomato paste processing and serves as the base for fixing the price to be paid to the producer.

$\mathrm{pH}$ values are crucial for processing tomatoes since values higher than 4.4 indicates susceptibility of the pulp to thermophilic pathogens [13]. Thus, $\mathrm{pH}$ values as low as possible (up to the point that it does not adversely affect taste) should be bred into tomato cultivars for industrial use [14]. It has been shown that sugar content is positively correlated with total soluble solids content in tomato fruit and in most cases this correlation is high $[6,15]$. Hence, the measurement of soluble solids content measurements may give a fair estimate of the sugar level in tomato fruit. The sugars are mostly glucose and fructose and constitute about $65 \%$ of total soluble solid in expressed fruit juice.

In this study, fruits harvested from $\mathrm{F}_{4}$ breeding lines of tomato were evaluated for their physico-chemical properties to identify genotypes with desirable fruit quality parameters from which selection can be made for further breeding work.

\section{Materials and Methods}

\subsection{Planting Materials}

Planting materials were obtained from an $\mathrm{F}_{3}$ generation of segregating lines of tomatoes on BNARI farms. The progenies were obtained as a result of crosses between a wild tomato (Solanum pimpinellifolium L.) and four different cultivated tomato (S. lycopersicon L.) varieties: cherry red, cherry yellow, roma and wosowoso. The $\mathrm{F}_{3}$ seeds were planted to obtain $\mathrm{F}_{4}$ fruits. The field experiment was conducted between May and August, 2012. The experimental design was a Randomised Complete Block Design (RCBD) with four replications. The seeds were nursed in plastic trays and after 21 days transferred onto the field (BNARI experimental plots). The fruits were grown under the same climatic conditions and were harvested almost around the same time.

Out of 20 accessions, four (4) parental (control) lines with their corresponding two progenies each were selected and tagged for the study. For all breeding lines, fruits that were roundish, reddish (fully ripe) free from insect pests and cracks were selected for the study. These progenies from each parental (control) stock were labelled lines 1 and 2.

\subsection{Sample Collection, Preparation and Analyses}

Fresh, wholesome and fully ripe fruits were harvested and sanitized by removing any extraneous materials such as soil particles and their peduncles. These fruits were analysed for their dry matter (DM) contents. About 200g of previously washed and dried tomato fruits were weighed into high density polypropylene bags, sealed and crushed for 3 minutes in a stomacher (Seward medical, UK). The fruit juice was then filtered through a sieve of $1 \mathrm{~mm}$ pore size facilitating the removal of fruit coats and seeds. The fruit juice obtained was analysed for $\mathrm{pH}$, total titratable acidity (TTA), total soluble solids (TSS), vitamin C (ascorbic acid), flavour index (FI) and sweetness index (SI).

\subsubsection{Dry Matter Content}

Percentage dry matter content of the fruits was determined by following the method as outlined in [17], with little modifications.

About $50 \mathrm{~g}$ of cleaned fruits (free from dirt and water droplets) was weighed into a previously washed and dried evaporating dish of a known weight. This was followed by drying the samples at $60^{\circ} \mathrm{C}$ to a constant weight in a hot air oven (Gallenkamp, United Kingdom) for a period of 72 hours. The experiment was run for each treatment in triplicates. The evaporating dishes with the dried samples were transferred onto desiccators with activated desiccants and allowed to cool for about 30 minutes and then re-weighed. The results were reported as the mean of the three results with a standard deviation for all the samples. The weight of each dried sample was expressed as a percentage of the fresh weight as shown by the following mathematical relation.

$$
\% \text { Dry Matter }=\left(\frac{W t . \text { ofDried Sample }(g)}{\text { Wt. of Fresh Sample }(g)}\right) \times 100
$$

\subsubsection{Total Soluble Solids}

The total soluble solid was determined using a portable refractometer (RHB-32 ATC, 0-32\% ATC Brix, China) as outlined by [16]. About $1 \mathrm{~mm}^{3}$ of the filtrate (juice) obtained from the fruit was applied onto the loading point of the refractometer and the brix readings were taken from the scale directly as percentage.

\subsection{3. $\mathrm{pH}$}

Determination of $\mathrm{pH}$ was carried using a $\mathrm{pH}$ meter $(\mathrm{pH}$ 213, Germany).

\subsubsection{Total Titratable Acidity}

Total titratable acidity (TTA) was carried as outlined in method 942.15 of [17]. A $10 \mathrm{ml}$ volume of extracted tomato juice was measured and mixed thoroughly in $50 \mathrm{ml}$ distilled water. The mixture was titrated against $0.1 \mathrm{M} \mathrm{NaOH}$ with three drops of phenolphthalein until a $\mathrm{pH}$ of 8.1 (pink) was attained. The volume of the sodium hydroxide $(\mathrm{NaOH})$ 
added to the solution was multiplied by a correction factor of 0.064 to estimate titratable acidity as percentage of citric acid. This was done for all samples in triplicates and mean values with their corresponding standard deviations calculated and reported using the following relation.

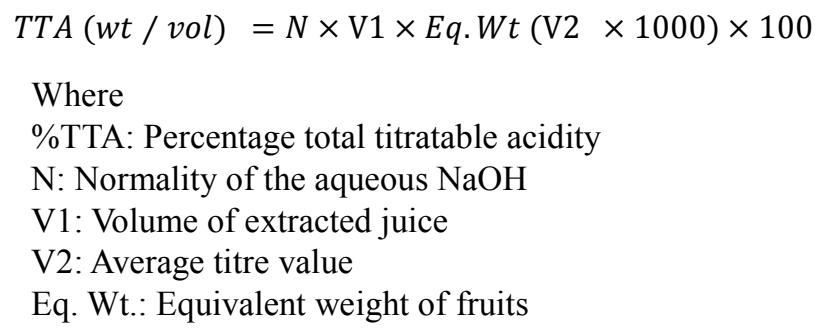

\subsubsection{Ascorbic Acid (Vitamin C)}

Ascorbic acid (vitamin $\mathrm{C}$ ) in tomato accessions was determined by using the Redox Titration method using iodine solution as outlined in [17]. A single vitamin $\mathrm{C}$ tablet was dissolved in $200 \mathrm{ml}$ of distilled water in a volumetric flask. Iodine solution of $0.005 \mathrm{~mol} / \mathrm{L}$ was prepared using $2 \mathrm{~g}$ of potassium iodide and $1.3 \mathrm{~g}$ of iodine dissolved in $1 \mathrm{~L}$ of distilled water in a volumetric flask. 1\% starch indicator solution was prepared by dissolving $0.5 \mathrm{~g}$ of potato starch in $50 \mathrm{ml}$ of distilled water. A mixture of $10 \mathrm{ml}$ vitamin $\mathrm{C}$ standard solution, $1 \mathrm{ml}$ of distilled water and $1 \mathrm{ml} 1 \%$ starch indicator solution titrated was against $0.005 \mathrm{~mol} / \mathrm{L}$ of iodine solution. Three replicates were done and the averages calculated.

A mixture of $10 \mathrm{ml}$ of tomato juice extract, $1 \mathrm{ml}$ of distilled water and $1 \mathrm{ml}$ of $1 \%$ starch indicator solution was titrated against $0.005 \mathrm{~mol} / \mathrm{L}$ of iodine solution. All titrations were done in triplicates and averages calculated. The ascorbic acid content was calculated according to the following relation.

$$
A A(g \mid L)=(x y / w) X 1000
$$

Where

\section{AA: Ascorbic Acid}

$\mathrm{w}$ : Volume (ml) of iodine solution for standard vitamin C $\mathrm{y}$ : Volume $(\mathrm{ml})$ of iodine solution (titre value)

$\mathrm{x}$ : Mass (g) of standard vitamin C

$\mathrm{z}=$ Mass $(\mathrm{g})$ of Vitamin $\mathrm{C}$ in Sample

\subsubsection{Flavour Index}

The flavour index (FI) was determined according to procedures outlined by [18] and expressed according to the following relation.

$$
\text { Flavour Index }=\frac{\text { Titratable Acidity }}{\text { Total Soluble Solids }}
$$

\subsubsection{Sweetness Index}

The sweetness index (SI) was determined by following procedures outlined by [18] and expressed according to the following relation.

$$
\text { Sweetness Index }=\frac{\text { Total Soluble Solids }}{\text { Titratable Acidity }}
$$

\subsection{Data Analyses}

Data Analysis was done using one-way ANOVA of SPSS version 16 (USA) to determine effect of varietal differences and progenies on various response variables. Significant difference was accepted at $\mathrm{P}<0.05$. Fisher's Least Significant Difference (LSD) was used for the mean separation.

\section{Results and Discussion}

\subsection{Dry Matter}

Significant differences $(\mathrm{p}<0.05)$ were detected among the dry matter contents for the fruits of the various tomato lines as indicated in Table 1 . No significant difference $(p>0.05)$ was observed in the dry matter contents for the fruits of the controls of cherry red and wosowoso (Table 1). Similarly no significant difference $(p>0.05)$ was observed in the dry matter contents for tomato fruits of both progenies of cherry red and one of the progenies of wosowoso (L2). Likewise, the dry matter contents for the fruits from both two progenies of cherry yellow were not significantly $(p>0.05)$ different from each other. However the percentage dry matter content for the fruits obtained from control stock was $7.44 \%$ which was significantly $(\mathrm{p}<0.05)$ more than those (6.37 and 6.03\%) for both progenies of cherry red. The per cent dry matter content for the fruits obtained from the progenies of cherry yellow $(8.08 \%$ for both) were significantly $(\mathrm{p}<0.05)$ higher than those obtained from the control samples $(5.33 \%)$. On the other hand both progenies and control stocks for tomatoes harvested from roma and wosowoso were significantly $(\mathrm{p}<0.05)$ different from one another as shown in (Table 1).

Among the progenies, wosowoso L1 had dry matter content of $8.43 \%$ being the highest whilst the lowest is that for the fruits of the progenies of roma (roma L1) being $4.85 \%$. Significantly $(\mathrm{p}<0.05)$ lower dry matter contents were observed for the fruits harvested from the progenies of cherry red from their control counterparts by $14.38 \%$ and $18.95 \%$ and roma by $10.52 \%$ and $3.87 \%$ for the L1 and L2 progenies respectively in both cases as shown in Table 1. The fruits of one of the progenies of wosowoso (L2), had its dry matter content significantly $(\mathrm{p}<0.05)$ lower by $15.32 \%$ than that of the control stock, whereas the other progeny had its dry matter content being significantly $(p<0.05)$ higher by $17.41 \%$ than the fruits of the control samples. The dry matter contents of the fruits for both progenies of cherry yellow were significantly $(\mathrm{p}<0.05)$ higher by $51.59 \%$ than the fruits of the parental control samples.

According to [19], the average dry matter of ripe fresh tomato fruit must be at least 5\%. There were significant differences observed in dry matter of the various accessions. This was similar to an earlier work done by [20] in which it 
was found to range from 3.87 to $7.0 \%$. In another study, the dry matter of the cultivars was found to be $6.20 \%$ [21]. The dry matter content was also reported to range from 7.63 to $8.72 \%$ [22]. In the processing of paste with the fruits, high dry matter improves the quality of the processed product [9]. The results obtained show that the dry matter for the fruits for all the accessions analysed were above $5 \%$ with the exception of Line 1 of roma which had a dry matter content of $4.85 \%$ and therefore suitable for industrial purposes.

\section{2. $\mathrm{pH}$}

Table 1. pH, Dry Matter and Total Soluble Solids content of fruits and juice extracts obtained from parents (controls) and two progenies each for four different accessions of tomato lines.

\begin{tabular}{lccc}
\hline $\begin{array}{c}\text { Tomato Parents } \\
\text { and Progenies }\end{array}$ & $\begin{array}{c}\text { Dry Matter } \\
(\%)\end{array}$ & pH & $\begin{array}{c}\text { Total Soluble } \\
\text { Solids (\%) }\end{array}$ \\
\hline Cherry red & & & \\
Control & $7.44^{\mathrm{c}} \pm 0.10$ & $4.29^{\mathrm{de}} \pm 0.20$ & $6.00^{\mathrm{b}} \pm 0.10$ \\
Line 1 & $6.37^{\mathrm{d}} \pm 0.03$ & $4.08^{\mathrm{e}} \pm 0.11$ & $5.00^{\mathrm{de}} \pm 0.06$ \\
Line 2 & $6.03^{\mathrm{d}} \pm 0.10$ & $4.49^{\mathrm{d}} \pm 0.20$ & $5.00^{\mathrm{de}} \pm 0.57$ \\
Cherry yellow & & & \\
Control & $5.33^{\mathrm{e}} \pm 0.51$ & $4.39^{\mathrm{cd}} \pm 0.20$ & $4.80^{\mathrm{e}} \pm 0.57$ \\
Line 1 & $8.08^{\mathrm{b}} \pm 0.11$ & $4.51^{\mathrm{c}} \pm 0.20$ & $5.70^{\mathrm{c}} \pm 0.00$ \\
Line 2 & $8.08^{\mathrm{b}} \pm 0.10$ & $4.56^{\mathrm{c}} \pm 0.03$ & $5.80^{\mathrm{bc}} \pm 0.05$ \\
Roma & & & \\
Control & $5.42^{\mathrm{e}} \pm 0.06$ & $4.55^{\mathrm{c}} \pm 0.22$ & $4.00^{\mathrm{f}} \pm 0.00$ \\
Line 1 & $4.85^{\mathrm{f}} \pm 0.05$ & $4.26^{\mathrm{def}} \pm 0.30$ & $5.00^{\mathrm{de}} \pm 0.10$ \\
Line 2 & $5.21^{\mathrm{ef}} \pm 0.11$ & $4.21^{\mathrm{def}} \pm 0.10$ & $4.00^{\mathrm{f}} \pm 0.05$ \\
Wosowoso & & & \\
Control & $7.18^{\mathrm{c}} \pm 0.12$ & $4.09^{\mathrm{ef}} \pm 0.02$ & $5.20^{\mathrm{d}} \pm 0.05$ \\
Line 1 & $8.43^{\mathrm{a}} \pm 0.06$ & $4.21^{\mathrm{def}} \pm 0.03$ & $7.80^{\mathrm{a}} \pm 0.00$ \\
Line 2 & $6.08^{\mathrm{d}} \pm 0.10$ & $4.59^{\mathrm{c}} \pm 0.02$ & $5.80^{\mathrm{bc}} \pm 0.05$ \\
\hline
\end{tabular}

The results are means of triplicates. Mean values in a column with same superscript are not significantly different $(p>0.05)$ from each other.

In general, various levels of significant differences $(\mathrm{p}<0.05)$ were detected in the $\mathrm{pH}$ values for the fruits of the progenies for various accessions and their control. There was no significant difference $(\mathrm{p}>0.05)$ between the $\mathrm{pH}$ values (4.08 and 4.49) as indicated in Table 1 for the juice samples obtained from the fruits of both progenies and that (4.29) obtained from the parental stocks for cherry red. However the juice extracts obtained from the fruits from both progenies were significantly different $(p<0.05)$ from each other in terms of the $\mathrm{pH}$. Similarly no significant $(\mathrm{p}>0.05)$ difference was observed between the $\mathrm{pH}$ values (4.51 and 4.56) for juice extracts of progenies of cherry yellow. There was no significant difference $(\mathrm{p}>0.05)$ in the $\mathrm{pH}$ values for the juice extracts from the control (4.39) samples and both progenies (4.51 and 4.56) of the cherry yellow. In the same way, there was no significant $(\mathrm{p}>0.05)$ difference between the $\mathrm{pH}$ values of both progenies for roma (4.26 and 4.21). The $\mathrm{pH}$ values for these two progenies were significantly $(p<0.05)$ lower (more acidic) than that from the juice extracted from their parental stocks $(4.55)$ by $6.4 \%$ and $7.5 \%$. The $\mathrm{pH}$ of the juice extract from the Line 2 of wosowoso had a $\mathrm{pH}$ value of 4.59 being significantly $(p<0.05)$ less acidic than that $(4.09)$ of the fruits of the parental (control) lines by $12.2 \%$. Though the $\mathrm{pH}$ value (4.21) for the juice extract from Line 1 of wosowoso was also less acidic than that of the parental stocks by $2.9 \%$, the difference was not significant ( $\mathrm{p}>0.05)$.

The $\mathrm{pH}$ of tomatoes is determined primarily by the acid content of the fruit. The acidity of the fruit is also important as a contributor to the flavour of tomato products. The rise in $\mathrm{pH}$ results in decrease in TTA and thus acid concentrations declining with maturity. $\mathrm{pH}$ below 4.3 reduces the risk of bacterial growth and below 4.5 halts proliferation of microorganisms during the industrial processing of tomatoes. Industrial processors of tomatoes in California typically specify a $\mathrm{pH}$ of 4.2 or 4.3 in their processed products and thus cultivars with high $\mathrm{pH}$ are not suitable for processing [20]. A wide range of $\mathrm{pH}$ was reported from 3.78 to 5.25 in one study [21] and from 4.08 to 4.34 in another [23]. A pH below 4.5 was reported to be desirable, since it has the potential of arresting the proliferation of microorganisms in the final product during industrial processing [24]. Comparing the range of $\mathrm{pH}$ obtained with this work, the $\mathrm{pH}$ observed was within the acceptable range for processing tomato paste except Lines 2 of both cherry yellow and wosowoso since they both had their $\mathrm{pH}$ values above 4.5 .

\subsection{Total Soluble Solids (The Brix)}

The brix for the fruits of the parental (control) samples (Table 1) was highest for cherry red (6.0\%) and lowest $(4.0 \%)$ for the fruits of roma. However among the fruit juice extracts of the progenies of the $4^{\text {th }}$ filial generation, wosowoso had the highest brix value of $7.8 \%$ whilst roma had $4.0 \%$ being the juice extract with the least total soluble solids. The brix values $(5.00 \%)$ for the fruits of both progenies of cherry red were significantly $(\mathrm{p}<0.05)$ lower by $1.00 \%(16.67 \%)$ than the brix $(6.00 \%)$ from their control (parent). The total soluble solids for the juice extracts from the fruits harvested from the two progenies of cherry red were not significantly $(p>0.05)$ different from each other. In contrast, the brix values were higher by $0.9 \%(18.75 \%)$ and $1.00 \%(20.83 \%)$ for the juice extracts from both lines (progenies) of cherry yellow than that for the fruits of the control samples. The total soluble solids for juice extracts from line 1 was $5.00 \%$, which was significantly $(\mathrm{p}<0.05)$ higher by $1.00 \%(25 \%)$ than that for the juice extracts from the line 2 and the control samples of roma. The percentage total soluble solids for the juice extract from the fruits of line 2 were not significantly different $(\mathrm{p}>0.05)$ from that of the control samples. The total soluble solids for the fruits of both progenies for wosowoso were also $2.60 \%(50 \%)$ and $0.6 \%$ $(11.54 \%)$ higher than that for juice extracts from the fruits of the control samples. Finally the percentage total soluble solids for the line 1 (progeny 1$)$ was significantly $(\mathrm{p}<0.05)$ higher than that for the juice extract from line 2 (progeny 2 ) by $2.00 \%(34.48 \%)$.

Total soluble solid (brix) is one of the most important 
quality factors for most fruits. A total soluble solid of 4.80 to $8.80 \%$ indicates the high quality of tomato [7]. According to [23], TSS must range from 5 to $6.5 \%$ in tomatoes for industrial processing; 5.50-5.12\% [21]; 5.0-5.5\% [23], 4-6\% [25]; 4.2\% and 4.5\% for Delvin F1 and Elvano F1 respectively [26-27]. The range of TSS obtained for the various accessions (4.0-7.8\%) is within acceptable range for processing and similar to the results obtained by [24] who stated that tomato cultivar IPA6 (industrial tomato) had TSS ranging from 5.0 to $5.5 \%$. In another studies [25], TSS ranged from 4 to $6 \%$. Similarly, total soluble solids of 4.5 and $4.2 \%$ was reported for Elvano F1 and Delfin F1 by [27], $4.58 \%$ for Uno (industrial tomato), 5.26\% for Rio Grande (industrial tomato), and $5.40 \%$ for $\mathrm{H}-2274$ (fresh tomato) [27].

\subsection{Total Titratable Acidity}

The total titratable acidity of the fruits of wosowoso was the highest $(0.82 \%)$ among the control accessions whilst that of cherry yellow was the least $(0.35 \%)$. However among the fruits for the progenies of the accessions for the $F_{4}$ generation, line 1 of wosowoso had the highest (0.88\%) total titratable acidity whereas the progenies of cherry yellow had the least $(0.352 \%)$. The total titratable acidity values for the fruits of both progenies for cherry yellow accession were significantly $(p<0.05)$ higher by $0.11 \%(31.43 \%)$ than the fruits of the control (parental) stocks. The titratable acidity for the fruits of one of the progenies for cherry red was significantly $(\mathrm{p}<0.05)$ higher by $0.06 \%(9.80 \%)$ whereas the fruits of the other progeny had significantly $(\mathrm{p}<0.05)$ lower titratable acidity by $0.15 \%(38.35 \%)$ than the fruits of the control samples. No significant $(p>0.05)$ difference was found between the titratable acidity values of the fruits for the progenies (lines 1 and 2) of roma. However fruits from both progenies of roma had their titratable acidity values higher than that for the fruits of their parental stocks by $0.15 \%$ $(22.03 \%)$ and $0.21 \%(28.05 \%)$. Also no significant $(\mathrm{p}>0.05)$ difference was found between the titratable acidity values for the fruits of the control samples and the progenies of wosowoso. However the titratable acidity values for the line 2 of wosowoso was significantly $(\mathrm{p}<0.05)$ lower than that of the control samples by $0.39 \%(47.56 \%)$.

Table 2. Total titratable acidity, vitamin C, flavour and sweetness indices for juice extracts obtained from two progenies and their respective parents (controls) for four different accessions of tomato lines.

\begin{tabular}{|c|c|c|c|c|}
\hline Tomato Parents and Progenies & Total Titratable Acidity (\%CA) & Ascorbic Acid (mg/100g) & Flavour Index & Sweetness Index \\
\hline \multicolumn{5}{|l|}{ Cherry red } \\
\hline Control & $0.55^{\mathrm{cd}} \pm 0.03$ & $46.09^{\mathrm{a}} \pm 1.18$ & $0.09^{\mathrm{e}} \pm 0.00$ & $10.87^{b} \pm 0.37$ \\
\hline Line 1 & $0.61^{\mathrm{c}} \pm 0.24$ & $21.78^{\text {cde }} \pm 0.86$ & $0.12^{\text {cd }} \pm 0.01$ & $8.20^{\text {cd }} \pm 0.68$ \\
\hline Line 2 & $0.40^{\mathrm{ef}} \pm 0.05$ & $19.05^{\mathrm{ef}} \pm 1.60$ & $0.08^{\mathrm{ef}} \pm 0.00$ & $12.54^{\mathrm{a}} \pm 0.52$ \\
\hline \multicolumn{5}{|l|}{ Cherry yellow } \\
\hline Control & $0.35^{\mathrm{f}} \pm 0.03$ & $25.29^{c} \pm 2.32$ & $0.07^{\mathrm{f}} \pm 0.00$ & $13.64^{\mathrm{a}} \pm 0.05$ \\
\hline Line 1 & $0.46^{\mathrm{e}} \pm 0.27$ & $34.58^{b} \pm 1.96$ & $0.08^{\mathrm{ef}} \pm 0.00$ & $12.48^{\mathrm{a}} \pm 1.29$ \\
\hline Line 2 & $0.46^{\mathrm{e}} \pm 0.01$ & $33.93^{\mathrm{b}} \pm 1.96$ & $0.08^{\mathrm{ef}} \pm 0.01$ & $12.48^{\mathrm{a}} \pm 0.57$ \\
\hline \multicolumn{5}{|l|}{ Roma } \\
\hline Control & $0.54^{\mathrm{d}} \pm 0.02$ & $21.06^{\text {cdef }} \pm 1.40$ & $0.14^{\mathrm{c}} \pm 0.00$ & $7.41^{\mathrm{de}} \pm 0.22$ \\
\hline Line 1 & $0.69^{\mathrm{b}} \pm 0.13$ & $16.84^{\mathrm{f}} \pm 1.30$ & $0.14^{\mathrm{c}} \pm 0.01$ & $7.23^{\mathrm{de}} \pm 0.49$ \\
\hline Line 2 & $0.75^{b} \pm 0.15$ & $20.15^{\mathrm{def}} \pm 2.83$ & $0.19^{\mathrm{a}} \pm 0.01$ & $5.33^{\mathrm{f}} \pm 0.14$ \\
\hline \multicolumn{5}{|l|}{ Wosowoso } \\
\hline Control & $0.82^{\mathrm{a}} \pm 0.03$ & $23.79^{\mathrm{cd}} \pm 1.38$ & $0.16^{\mathrm{b}} \pm 0.01$ & $6.35^{\mathrm{ef}} \pm 0.41$ \\
\hline Line 1 & $0.88^{\mathrm{a}} \pm 0.01$ & $37.11^{b} \pm 1.69$ & $0.11^{\mathrm{d}} \pm 0.00$ & $8.90^{\mathrm{c}} \pm 0.20$ \\
\hline Line 2 & $0.43^{\mathrm{e}} \pm 0.00$ & $33.05^{\mathrm{b}} \pm 1.67$ & $0.08^{\mathrm{ef}} \pm 0.01$ & $13.35^{\mathrm{a}} \pm 0.56$ \\
\hline
\end{tabular}

The results are means of triplicates. Mean values in a column with same superscript are not significantly different ( $\mathrm{p}>0.05)$ from each other.

The total titratable acidity (TTA) content of tomato fruit for industrial processing should range from 0.35 to $0.88 \%$ in the study. In a similar work using 12 different tomato genotypes, total titratable acidity values in the range of 0.25 to 0.70 , for Elnova F1, and 0.25 to 0.44 for Delfin F1 green house cultivars were reported [24]. Similarly previous works also reported values in the range of 0.22 to $0.40 \%$; [20], 0.25 to $0.70 \%$ [28]. Tomato consists of $94-95 \%$ water, $5-6 \%$ organic compounds (solids) of which about $1 \%$ is skin and seeds [11]. The percentage total titratable acidity in tomatoes varies over wide limits for a number of reasons; such as variety, character of soil and especially the amount of irrigation and rainfall during growing and harvesting season [11].

\subsection{Vitamin C (Ascorbic Acid)}

The vitamin $\mathrm{C}$ content of fruits harvested from cherry red control was $46.09 \mathrm{mg} / 100 \mathrm{~g}$ being the highest for the juice extracts for fruits harvested from the parental (control) lines, whereas $16.84 \mathrm{mg} / 100 \mathrm{~g}$ was the least vitamin $\mathrm{C}$ content for juice extracts obtained from fruits harvested from line 1 of roma (Table 1). Significant $(p<0.05)$ differences were detected in the vitamin $\mathrm{C}$ contents of juice extracts obtained from fruits harvested from the accessions. Juice extracts from cherry red control were significantly $(\mathrm{p}<0.05)$ higher than those obtained from juice extracts from both of its progenies. The vitamin $\mathrm{C}$ content of fruits harvested from line 1 of cherry red was significantly $(\mathrm{p}<0.05)$ higher than that of line 2. The extracted juice from the fruits of both lines 
of cherry yellow had vitamin C contents significantly $(p<0.05)$ higher by $9.29 \mathrm{mg} / 100 \mathrm{~g} \quad(36.73 \%)$ and 8.64 $\mathrm{mg} / 100 \mathrm{~g}(34.16 \%)$ respectively than the juice extracts from the fruits of their parental lines. There was no significant $(p>0.05)$ difference in the vitamin $C$ content of juice extracts of fruits harvested from both lines of cherry yellow. Juice extracts from the parental lines of roma had vitamin $\mathrm{C}$ content being $21.06 \mathrm{mg} / 100 \mathrm{~g}$ which was not significantly different $(\mathrm{p}>0.05)$ from that of both its progenies (16.84 and $20.15 \mathrm{mg} / 100 \mathrm{~g})$. In contrast the vitamin $C$ level of fruits from the parental lines of wosowoso was significantly different from that of both of its progenies. However vitamin $\mathrm{C}$ levels of fruits from the two progenies (lines) of wosowoso were not significantly different $(\mathrm{p}>0.05)$ from each other. The fruits of lines 1 and 2 of this accession had vitamin $\mathrm{C}$ contents significantly higher $(\mathrm{p}<0.05)$ by $13.32(55.99 \%)$ and $9.26(38.92 \%) \mathrm{mg} / 100 \mathrm{~g}$ than fruits harvested from the control samples.

In a similar work to study of influence of post-harvest treatments and storage conditions on ascorbic acid levels in tomato fruits for 7 days of storage by [29], 23.66 to 30.94 $\mathrm{mg} / 100 \mathrm{~g}$ was reported for fruits stored under ambient condition, where 24.57 to $31.85 \mathrm{mg} / 100 \mathrm{~g}$ of ascorbic acid was reported for those stored under refrigeration. In another study to evaluate the effect of cultivar and fertilizer on vitamin $\mathrm{C}$ content of tomatoes, values between 11.31 and $12.73 \mathrm{mg}$ per $100 \mathrm{~g}$ was reported for table ripe fruits [30].

\subsection{Flavour Index}

Significant differences $(p<0.05)$ were detected in the flavour indices of the tomato fruits (Table 1). The juice of the fruits harvested from the line 2 of roma had the highest flavour index of 0.187 , followed by fruits from the parental lines of wosowoso being 0.160 , this was followed by the fruits of the line 1 and the control samples of roma being 0.137 and 0.135 respectively which were not significantly different $(\mathrm{p}>0.05)$ from each other. This was followed by 0.123 being the flavour index for the juice extracted from fruits of line 1 of cherry red and then followed by 0.110 being the flavour index for juice obtained from the fruits of the line 1 of wosowoso. In contrast the juice obtained from fruits of the control samples of cherry yellow had the least flavour index being 0.070 followed by that obtained from the fruits of the control stocks of cherry red being 0.090 . This was followed by juice samples obtained from fruits of line 2 of wosowoso (0.077), line 2 of cherry red (0.080) progenies 1 and 2 of cherry yellow (0.080). However the differences in these flavour indices were not significantly different $(\mathrm{p}>0.05)$ from one another.

Aromas (flavours) play an important role in the choice of food by humans. Flavour, besides other parameters such as texture and appearance, plays a very important role in the quality assessment of fruits and vegetables. Flavour is a combination of taste and flavour sensations. The pleasant sweet-sour taste of tomatoes is mainly due to their sugar and organic acid contents. Of the over 400 volatiles determined, 30 have proved to be the most important compounds contributing to the flavour of tomatoes [19]. The characteristic flavour of tomatoes is produced by the complex interaction of the volatile and non-volatile components [19]. The characteristic sweet-sour taste of tomato is due to a combination of the sugars and organic acids present. The total sugar content of ripe tomato is between 1.7 and $4.7 \%$ [19]. It was demonstrated addition of sugars increased flavour acceptability when the sample has a $\mathrm{pH}$ near 3.74 (or $0.80 \%$ titratable acidity) but did not affect the tomato-like character of fresh tomatoes [6]. High correlations between sourness, titratable acidity (TA) and $\mathrm{pH}$ was observed in another study [4]. Reducing sugars and free amino acids are precursors of a great number of flavour compounds. Free amino acids react with reducing sugars in Maillard reactions or Strecker degradations. Sometimes they are thermally degraded. The result is the pleasant smell arising from a freshly opened ground coffee package, which is an indicator of quality.

\subsection{Sweetness Index}

Significant differences $(p<0.05)$ were observed in the sweetness indices for the juice samples extracted from the fruits of both progenies and the control samples of different varieties of tomato fruits. The juice extracted from the fruits harvested from the parental (control) lines of cherry yellow has the highest sweetness index being 13.64. This was followed by that of the juice extracted from the fruits harvested from the line 2 of wosowoso being 13.35. The juice from fruits of line 2 of cherry red had a sweetness index of 12.54 being third highest. This was followed by the sweetness indices of juice obtained from the fruits harvested from lines 1 and 2 of cherry yellow. However the differences in these sweetness index values were not significantly different $(p>0.05)$ from one another. The fifth, sixth and seventh highest sweetness indices were 10.87, 8.90 and 8.20 for the juice extracts from fruits harvested from control samples of cherry red, line 1 of wosowoso and line 1 of cherry red respectively. The eighth and ninth sweetness indices were 7.41 and 7.23 for the fruits of line 1 and the control samples of roma respectively and similarly no significant difference $(p>0.05)$ was detected between these two. The tomato juice with the least sweetness index (5.33) was for fruits harvested from line 2 of roma.

In a study to assess the quality of MD2 pineapple variety with respect to the other varieties on the Ghanaian market, the evaluation of the sweetness index values of various blends of pineapple juice ranged from 6.98 to 15.14 [17]. However the current study ranged from 5.33 to 13.64 for the tomato juice extracts. This range was almost similar to that of the earlier study [17].

\section{Conclusion}

Fruits of most of the progenies (lines 1 and 2) of the breeding lines out-performed their parents in terms of acquiring physico-chemical qualities that was closer to standards required for industrial processing unlike fruits 
harvested from their respective parents. This suggested that hybridization and the selection of desirable breeds had resulted in the improvement of already existing varieties. This study also indicates that through hybridization, the ascorbic acid of the various accessions have been tremendously improved with the highest Vitamin $\mathrm{C}$ being $34.58 \mathrm{mg}$ per $100 \mathrm{~g}$ of fruits as found in progeny (line) 2 of cherry yellow.

\section{Acknowledgement}

Authors are grateful to Prof. Josephine Nketiah-Tabiri, the former Director of Biotechnology and Nuclear Agriculture Research Institute (BNARI), for the opportunity to use equipment at the institute for the project. We also thank technicians and colleagues at the Nuclear Agriculture Research Centre and the Laboratories of the Radiation Technology Centre who contributed numerously in carrying out this work.

\section{References}

[1] Tambo, J.A. and Gbemu, T. Resource-use Efficiency in Tomato Production in the Dangme West District, Ghana. Conference on International Research on Food Security, Natural Resource Management and Rural Development. Tropentag, ETH Zurich, Swzld. 2010.

[2] Stevens MA. Varietal influence on nutritional value. In PL White and N Selvey (eds.). Nutritional qualities of fresh fruits and vegetables. Futura Publ. Co., Mt. Kisco, N.Y., 1974; $87-110$.

[3] Sablani SS, Opara LU, Al-Balushi K. Influence of bruising and storage temperature on vitamin $\mathrm{C}$ content of tomato fruit. J. Food Agric. Environ., 2006; 4(1):54-56.

[4] Stevens MA, Kader AA, Albright-Holton M, Algazi M. Genotypic variation for flavor and composition in fresh tomatoes. J. Am. Soc. Hortic. Sci., 1977; 02:880-689.

[5] Stevens MA, Kader AA, Albright M. Potential for increasing tomato flavour via increased sugar and acid content. J. Amer. Soc. Hort. Sci. 1979; 102(6):724-731.

[6] Malundo TMM, Shewfelt RL, Scott JW. Flavor quality of fresh market tomato (Lycopersicon esculentum Mill.) as affected by sugar and acid levels. Post-harvest Biol. Technol., $1995 ; 6: 103-110$.

[7] Arazuri S, Jaren C, Arana JI, Perez De Ciriza JJ. Influence of mechanical harvest on the physical properties of processing tomato. J. Food Eng. 2007; 80:90-198.

[8] Artes F, Conesa MA, Hernandez S, Gill MI. Keeping quality of fresh-cut tomato. Post-harvest Biol. Technol., 1999; $17: 153-162$.

[9] DePascale S, Maggio A, Fogliano V, Ambrosino P, Retieni A. Irrigation with saline water improves carotenoids content and antioxidant activity of tomato. J. Horticl. Sci. Biotechnol., 2001; 76:447-453.

[10] Davies JN, Hobson LE. The constituents of tomato fruit, the influence of environment, nutrition and genotype. C.R.RC. Critical Rev. Food Sci. Nutrition. 1981; 15:205-80.
[11] Jongen W. Fruit and vegetables processing. Wood head publishing in Food Sci. and Technol. Wagenningen University, Netherlands, 2002; 350.

[12] Mizrahi Y, Taleisnik E, Kagan-Zur V, Zohas Y, Offenbach R, Matan R, Golan E. A saline irrigation regime for improving tomato fruit quality without reducing yield. J. Am. Soc. Hortic. Sci., 1988; 113:202-205.

[13] Paulson KN, Stevens MA. Relationships among titratable acidity, $\mathrm{pH}$ and buffer composition of tomato fruits. J. Food Sci., 1974; 39:254-357.

[14] Georgelis N. High fruit sugar characterization, inheritance and linkage of molecular markers in tomato. A Thesis Presented to the Graduate School of the University of Florida in Partial Fulfillment of the Requirement for the Degree of Master of Sci. University of Florida, 2002; 71.

[15] Saliba-Colombani V, Causse M, Langlois D, Philouze J, Buret M. Genetic analysis of organoleptic quality in fresh market tomato: Mapping QTLs physical and chemical traits. Theor. Appl. Genet. 2001; 102:259-272.

[16] Tigchelaar EC. Tomato breeding. In: Basset M.J. (ed.) Breeding vegetables crops. Westport, USA, AVI Publishing Co., Inc.: 1986; 135-170.

[17] Official Methods of Analysis of the Association of Official Analytical Chemists (AOAC). 15th Ed. Arlington, Va; 1990.

[18] Wardy W, Saalia FK, Steiner-Asiedu M, Budu AS, Sefa-Dedeh S. A comparison of some physical, chemical and sensory attributes of three pineapple (Ananas comosus) varieties grown in Ghana. African Journal of Food Science 2009; 3(1):022-025.

[19] Petro-Turza M. Flavour of tomato and tomato products. Food Rev. Int. 1987; 2(3):309-351.

[20] Turhan A, Sentz V. Estimation of certain chemical constituents of fruits of selected tomato genotypes grown in Turkey. African Journal of Agricultural Research 2009; 4(10):1086-1092

[21] Salunkhe DK, Desai BB. Post-harvest biotechnology of vegetables. Vol. II. CRC Pres, Boca Raton, FL. 1984; 288.

[22] Rosales MA, Cervilla LM, Sánchez-Rodríguez E, Rubio-Wilhelmi M, Blasco B, Ríos JJ, Soriano T, Castilla N, Romero L, Ruiz JM. The effect of environmental conditions on nutritional quality of cherry tomato fruits: Evaluation of two experimental Mediterranean greenhouses. J. Sci Food Agric. 2011; 91:152-162.

[23] Cemeroglu B, Karadeniz F, Ozkan M. Meyvesebzeislemeteknolojisi. Gida Teknolojisi Yayınları (in Turk1sh), 2003; 28:469-472.

[24] Giordano LB, Silva JBC, Barbosa V. Escolha de cultivars e plantio. In: Silva JBC and Guarding LB (org) Tomatoe paraprocessamento industrial. Brasilia: Emrapa, $\mathrm{CNPH}$, 2000; 36-59.

[25] Alcantar GG, Villarreal MR, Aguilar AS. Tomato growth and nutrient utilization in response to varying fertigation programs. Acta Hortic. 1999; 481:85-391.

[26] Sen F, Ugur A, Bozokalfa MK, Esiok D, Boztok K. Determination of yield, quality and storage properties of some greenhouse tomato cultivars (in Turkish). Aegean University Agric. Faculty J., 2004; 41(2):9-17. 
[27] Kuzucu C, Kaynas K, Kuzucu F.C, Erken NT, Kaya S, Daydır HU. Bazı domates çeşitlerinin verim ve kalite özelliklerinin belirlenmesi (Determination of yield and quality characteristics of some tomato varieties). In: V. Sebze tarımı sempozyumu bildiri kitab1, 2004; 288-294.

[28] George B, Kaur C, Khurdiya DS, Kapoor HC Antioxidant in tomato as a function of genotype. Food Chem. 2004; $84: 45-51$
[29] Okolie NP, Sanni TE. Effect of post-harvest treatments on quality of whole tomatoes. African Journal of Food Science 2012; 6:70-77.

[30] Gull DD, Locascio SJ, Kostewicz SR. Composition of greenhouse tomatoes as affected by cultivar, production media and fertilizer. Proc. Fla. State Hort. Soc. 1977; 90:395-397. 